\title{
Zinc Detoxification Is Required for Full Virulence and Modification of the Host Leaf lonome by Xylella fastidiosa
}

\author{
Fernando Navarrete and Leonardo De La Fuente \\ Department of Entomology and Plant Pathology, Auburn University, Auburn, AL 36849, U.S.A. \\ Submitted 28 July 2014. Accepted 13 November 2014.
}

\begin{abstract}
Zinc (Zn) is an essential element for all forms of life because it is a structural or catalytic cofactor of many proteins, but it can have toxic effects at high concentrations; thus, microorganisms must tightly regulate its levels. Here, we evaluated the role of $\mathrm{Zn}$ homeostasis proteins in the virulence of the xylem-limited bacterium Xylella fastidiosa, causal agent of Pierce's disease of grapevine, among other diseases. Two mutants of $X$. fastidiosa 'Temecula' affected in genes which regulate $\mathrm{Zn}$ homeostasis (zur) and $\mathrm{Zn}$ detoxification $(c z c D)$ were constructed. Both knockouts showed increased sensitivity to $\mathrm{Zn}$ at physiologically relevant concentrations and increased intracellular accumulation of this metal compared with the wild type. Increased $\mathrm{Zn}$ sensitivity was correlated with decreased growth in grapevine xylem sap, reduced twitching motility, and downregulation of exopolysaccharide biosynthetic genes. Tobacco plants inoculated with either knockout mutant showed reduced foliar symptoms and a much reduced $(c z c D)$ or absent (zur) modification of the leaf ionome (i.e., the mineral nutrient and trace element composition), as well as reduced bacterial populations. The results show that detoxification of $\mathrm{Zn}$ is crucial for the virulence of $X$. fastidios $a$ and verifies our previous findings that modification of the host leaf ionome correlates with bacterial virulence.
\end{abstract}

Metal elements are essential for all forms of life, due to their function as structural or catalytic cofactors of proteins. It is estimated that almost $50 \%$ of proteins contain a metal cofactor (Helman et al. 2007; Waldron et al. 2009), and metals also act as stabilizers of cell membranes and cell walls (Chvapil 1973; Datnoff et al. 2007). Nonetheless, accumulation of metals beyond their optimal concentrations leads to toxicity due to competition for active sites with other metals, induction of oxidative stress, and inhibition of cell respiration (Chvapil 1973; Hobman et al. 2007). For these reasons, their intracellular concentrations must be tightly regulated.

During plant-microbe interactions, high levels of metals can restrict host colonization by microbial pathogens and be utilized as a defense mechanism by the host. This has been demonstrated in particular in metal hyperaccumulating plants, which accumulate extremely high concentrations of metal elements in aboveground parts. High levels of metals offer protection against herbivores and pathogens (Boyd 2012; Fones and Preston 2013;

Corresponding author: L. De La Fuente: Telephone: +1.334.844.2582; Fax: +1.334.844.1947; E-mail: 1zd0005@auburn.edu

*The $e$-Xtra logo stands for "electronic extra" and indicates that two supplementary tables are published online.

(c) 2015 The American Phytopathological Society
Fones et al. 2010); therefore, resistance to high levels of zinc $(\mathrm{Zn})$, cadmium $(\mathrm{Cd})$, and nickel $(\mathrm{Ni})$ are essential traits for microbial colonization of these plants (Fones et al. 2010; Ghaderian et al. 2000). Metals also play a role in the interactions between nonhyperaccumulating plants and their associated microorganisms. An example is that of the take-all disease fungus, Gaeumannomyces graminis var. tritici, where fungal ability to oxidize host manganese (Mn) correlates with virulence (Pedler et al. 1996). Copper (Cu) can restrict microbial colonization of the host, as was shown with beneficial Pseudomonas fluorescens, which requires $\mathrm{Cu}$ detoxification genes for plant colonization (Zhang and Rainey 2007, 2008). Furthermore, in the bacterial pathogen Xanthomonas oryzae pv. oryzae, a transcription activator-like effector is expressed in planta that induces the expression of $x a 13$, a rice gene that acts to reduce the $\mathrm{Cu}$ concentration in the xylem, promoting host bacterial colonization (Yuan et al. 2010). Xanthomonas spp. also require Zn homeostasis genes in order to colonize their plant hosts and be fully virulent. In these bacteria, mutations in zinc uptake regulator (zur), a Zn-dependent transcriptional regulator of the fur family (Patzer and Hantke 1998), limits their ability to grow in media supplemented with $\mathrm{Zn}$ and to produce exopolysaccharide (EPS). However, the defect in virulence was attributed to reduced EPS production or reduced tolerance to reactive oxygen species rather than to reduced $\mathrm{Zn}$ tolerance (Tang et al. 2005; Yang et al. 2007).

Xylella fastidiosa is a member of the family Xanthomonadeaceae that exclusively colonizes the xylem vessels of its host plants and the foregut of its insect vectors, where it grows predominantly as biofilms. This bacterium has a wide host range and causes many economically important diseases, such as Pierce's disease of grapevine and citrus variegated chlorosis (Chatterjee et al. 2008; Hopkins and Purcell 2002). Plants infected with $X$. fastidiosa show symptoms such as leaf scorching and chlorosis, among others. Disease is believed to be caused by plugging of the xylem vessels due to either bacterial biofilms or plant-derived substances (Chatterjee et al. 2008; Sun et al. 2013). Infected plants experience water stress as well as altered expression of genes involved in nutrient uptake (Choi et al. 2013). Analysis of the mineral composition of diseased plants shows alterations in their xylem sap and leaf ionome (De La Fuente et al. 2013; Oliver et al. 2014), defined as "the mineral nutrient and trace element composition of an organism" (Lahner et al. 2003). Moreover, it was recently demonstrated that, in $X$. fastidiosa-infected plants, modification of host leaf ionome correlates with bacterial virulence (Oliver et al. 2014).

$X$. fastidiosa presents several characteristics that make it attractive for the study of the effects of metals in plant-pathogen interactions. In particular, its restriction to the xylem vessels colocates this bacterium with the site of mineral element transport throughout the plant. Furthermore, in addition to the aforementioned 
host ionome modification, this bacterium accumulates high levels of metals $(\mathrm{Cu}, \mathrm{Zn}$, and $\mathrm{Mn}$ ) in its biofilm cells (important for virulence of this bacterium), as compared with planktonic cells (Cobine et al. 2013). Additionally, several metal elements (calcium [Ca], magnesium $[\mathrm{Mg}]$, and iron $[\mathrm{Fe}]$ ) are known to promote the expression of virulence traits (Andersen et al. 2007; Cruz et al. 2012; De La Fuente et al. 2014; Zaini et al. 2008) whereas others ( $\mathrm{Cu}$ and $\mathrm{Zn}$ ) have deleterious effect on growth and biofilm production (Cobine et al. 2013; Navarrete and De La Fuente 2014; Rodrigues et al. 2008).

In our previous study (Navarrete and De La Fuente 2014), we showed that high levels of $\mathrm{Zn}$ are deleterious for $X$. fastidiosa grown in batch cultures. However, this metal element also induces the production of large biofilm-like structures under flow conditions and increased amounts of EPS, a pathogenicity factor in this bacterium (Killiny et al. 2013). Thus, we wanted to investigate whether the $\mathrm{Zn}$ levels present in the host plant are enough to affect $X$. fastidiosa growth and virulence. We constructed knockout mutants of genes involved in $\mathrm{Zn}$ homeostasis: (i) the zur homolog of $X$. fastidiosa and (ii) cadmium zinc cobalt resistance $\mathrm{D}(c z c D)$, a gene that encodes a membrane bound ion transporter of the cation diffusion facilitator (CDF) family involved in Zn efflux (Anton et al. 1999; Huang et al. 2008; Nies 2003), for which there are no reports on its role during pathogen-plant host interactions. Results show that zur and $c z c D$ are necessary for growth of $X$. fastidiosa in media supplemented with physiologically relevant levels of $\mathrm{Zn}$ and with grapevine xylem sap. Nicotiana tabacum (a model host) inoculated with zur or $c z c D$ mutants exhibited noticeably reduced symptoms and a much reduced or absent alteration of the leaf ionome compared with plants inoculated with wild-type (WT) $X$. fastidiosa. Our results suggest that host $\mathrm{Zn}$ levels can limit the growth of this bacterium in planta and interfere with virulence.

\section{RESULTS}

Growth and biofilm production of $z u r$ and $c z c D$ mutants in media supplemented with $\mathrm{Zn}$ or grapevine xylem sap.

Previously, we screened the genome of $X$. fastidiosa for genes involved in Zn homeostasis (De La Fuente et al. 2014). We found that $X$. fastidiosa has homologs of genes involved in $\mathrm{Zn}$ uptake regulation (zur) and efflux $(c z c A B C$ and $c z c D)$ but incomplete or absent systems for $\mathrm{Zn}$ influx ( $z n u A B C$ and $z n u D$ ). To evaluate the role of $\mathrm{Zn}$ in the virulence of $X$. fastidiosa, two knockout mutants, zur (PD1849) and $c z c D$ (PD1811), were constructed by homologous recombination. Growth and biofilm production of the WT, zur, and $c z c D$ strains were evaluated in media supplemented with $\mathrm{ZnSO}_{4}$ or grapevine xylem fluid (sap). When grown in PD2 (Davis et al. 1981b), which has a Zn concentration of approximately $2.5 \mu \mathrm{M}$ (Cobine et al. 2013), all bacterial strains showed the same overall growth kinetics as measured by optical density at $600 \mathrm{~nm}\left(\mathrm{OD}_{600}\right)$ (Fig. 1A). Biofilm production, measured 7 days postinoculation (dpi), was not significantly $(P=0.5009)$ different among the three strains (Fig. 1E). When PD2 was supplemented with 25, 100, or 400 $\mu \mathrm{M} \mathrm{ZnSO}$, all strains showed reduced growth (Fig. 1B-D) compared with growth in PD2 but this reduction was more pronounced for the mutants. In PD2 supplemented with $25 \mu \mathrm{M}$ $\mathrm{ZnSO}_{4}$, both mutants showed slower growth kinetics than the WT. By 7 dpi, the OD $_{600}$ of the WT cultures was 1.5 and 2 times higher than those of $c z c D$ and zur cultures, respectively (Fig. 1B). Biofilm production in this medium was significantly higher for zur than for the WT $(P=0.0011)$, whereas $c z c D$ biofilm production did not differ from the WT (Fig. 1F). In PD2 supplemented with $100 \mu \mathrm{M} \mathrm{ZnSO}_{4}$, growth of both mutants was highly reduced compared with the WT, and an exponential phase was not observed for the mutants during the incubation
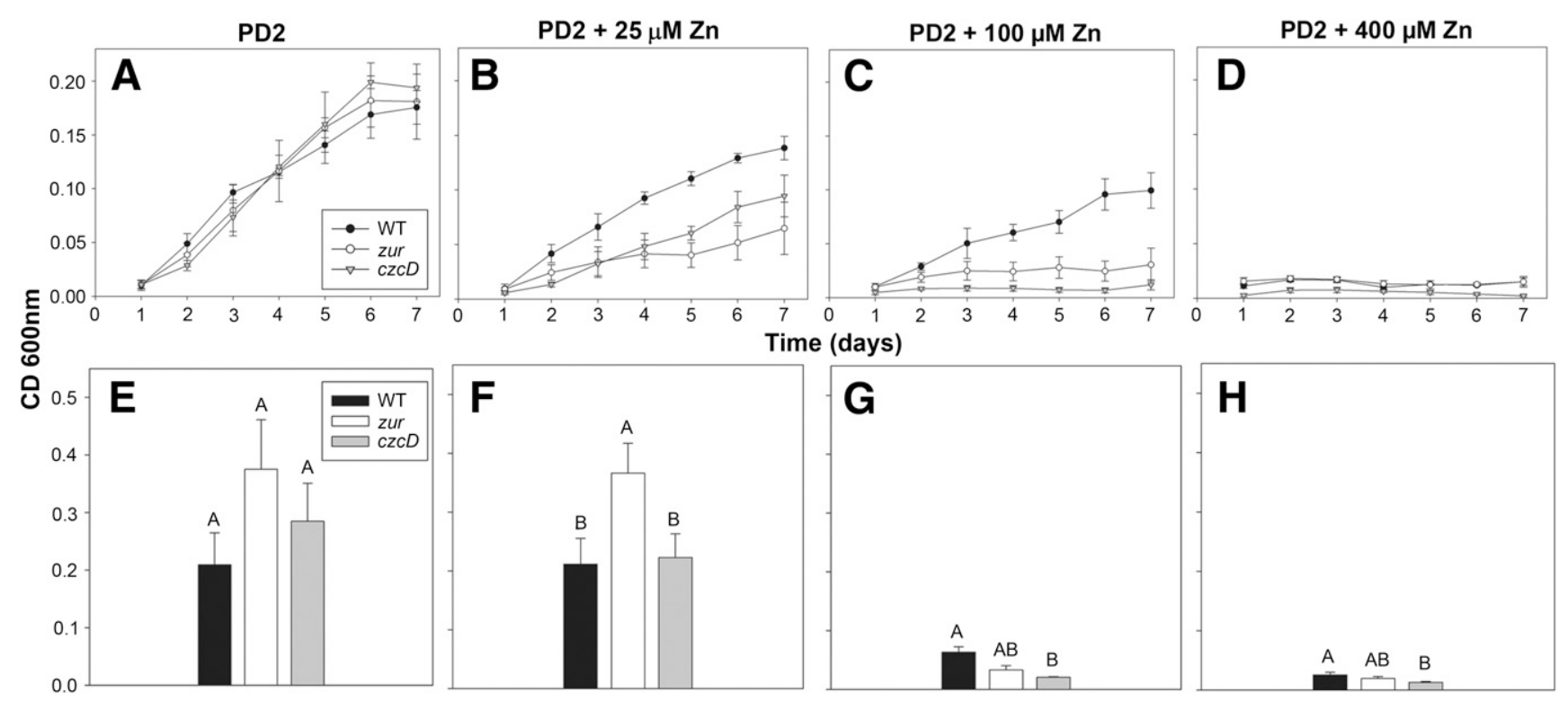

Strain
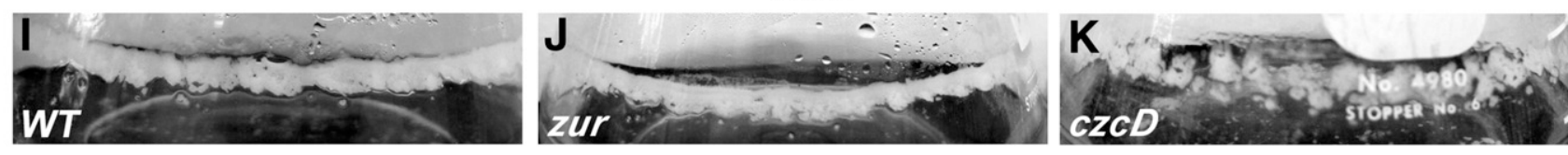

Fig. 1. Growth and biofilm formation of Xylella fastidiosa strains in plain media and media with different levels of Zn supplementation. A to D, Growth curves of wild-type (WT), zur, and $c z c D$ strains grown in $\mathbf{A}$, PD2 or PD2 supplemented with $\mathbf{B}, 25$; $\mathbf{C}, 100$; or $\mathbf{D}, 400 \mu \mathrm{M}$ ZnSO 4 for 7 days. $\mathbf{E}$ to $\mathbf{H}$, Biofilm formation of WT, zur, and $c z c D$ strains grown in $\mathbf{E}$, PD2 or PD2 supplemented with $\mathbf{F}, 25 ; \mathbf{G}, 100$; or $\mathbf{H}, 400 \mu \mathrm{M} \mathrm{ZnSO}_{4}$ for 7 days. I to $\mathbf{K}$, Pictures of biofilms formed on flask walls by WT, zur, and $c z c D$ strains grown in PD2. Note that $c z c D$ biofilms appear to flake off from the flask walls. Different letters indicate statistical differences $(P<0.05)$ according to analysis of variance and least significant difference test. Each data point represents mean \pm standard error of the mean $(n=6)$. Data presented in A to $\mathrm{H}$ were obtained from five independent experiments. 
period (Fig. 1C). Biofilm production was also reduced for both mutants compared with the WT $(P=0.0103)$ (Fig. 1G). In PD2 supplemented with $400 \mu \mathrm{M} \mathrm{ZnSO}_{4}$, all strains had greatly reduced growth and lacked an exponential phase during the incubation period (Fig. 1D). Biofilm production was much reduced for all strains, and $c z c D$ produced significantly less biofilm than the WT or zur strains $(P=0.0674)$. Biofilm production did not differ between the WT and zur (Fig. $1 \mathrm{H})$. Interestingly, biofilms produced by $c z c D$ showed a distinctive appearance compared with those of the WT or zur when grown in PD2, regardless of the $\mathrm{Zn}$ concentration. $c z c D$ biofilms appeared thinner than those of the WT, were scattered on the flask walls, and tended to flake off. Biofilms produced by the WT and zur were thick, continuous along the flask walls, and did not flake off as easily as those of $c z c D$ (Fig. 1I to K).

Supplementation of PD2 with grapevine xylem sap also had an inhibitory effect on the growth of $X$. fastidiosa, which was also more pronounced for the mutants than for the WT. When the strains were grown in a 1:1 (vol/vol) mix of PD2 and sap (50\% sap), the growth of both zur and $c z c D$ was much reduced compared with the WT. Cultures of the WT reached an $\mathrm{OD}_{600}$ two times higher than those of any of the mutant strains (Fig. 2A). Biofilm production was reduced in zur and $c z c D$ strains to approximately half of the WT $(P=0.0840)$ (Fig. 2C). Growth of all three strains was reduced in pure grapevine sap and no significant differences in biofilm formation $(P=0.7453)$ were observed among them (Fig. 2B and D).

\section{Ionomic changes of $z u r$ and $c z c D$ knockout mutants in response to high $\mathrm{Zn}$ levels.}

To confirm that zur and $c z c D$ participate in $\mathrm{Zn}$ efflux in $X$. fastidiosa, a Zn-shock experiment was performed. Briefly, WT, $z u r$, and $c z c D$ strains were grown in PD2 for 3 days; then, media were supplemented with $100 \mu \mathrm{M} \mathrm{ZnSO}_{4}$ and cultures were further incubated overnight. Then, cellular $\mathrm{Zn}$ amounts, as well as amounts of other elements, were measured by inductively coupled plasma with optical emission spectrometry (ICPOES). In the planktonic phase, both zur and $c z c D$ mutants showed increased $\mathrm{Zn}$ accumulation compared with the WT $(P=0.001)$ (Fig. 3A). zur and $c z c D$ accumulated approximately 38 and $46 \%$ more $\mathrm{Zn}$, respectively, than the WT. In addition, accumulation of other elements by planktonic cells was altered in both mutants: amounts of $\mathrm{Mg}(P<0.001)$ and phosphorus $(\mathrm{P})(P<0.001)$ were significantly increased and amounts of $\mathrm{Ca}(P=0.020), \mathrm{Fe}(P=0.001)$, and sodium $(\mathrm{Na})$ $(P=0.014)$ were significantly reduced compared with the WT (Fig. 3A). Only mutant $c z c D$ had reduced amounts of $\mathrm{Cd}$ $(P=0.045)$ compared with the WT. In biofilms, both mutants showed a significant accumulation of $\mathrm{Zn}(P=0.001)$ compared with the WT of approximately 19\% (zur) and 20\% $(c z c D)$. In zur only, Fe was significantly reduced $(P<0.001)$ and $\mathrm{Mg}$ was increased $(P=0.027)$ compared with the WT (Fig. 3B).

\section{Twitching motility of $z u r$ and $c z c D$ mutants.}

The twitching motility of the three $X$. fastidiosa strains was evaluated by measuring the colony fringe width on plain PW agar and PW agar (Davis et al. 1980) supplemented with 25 or $100 \mu \mathrm{M} \mathrm{ZnSO}$. In all conditions, both zur and $c z c D$ had reduced twitching motility (indicated by decreased fringe width) compared with the WT $(P<0.05)$ (Fig. 4). In plain PW $(3.0 \mu \mathrm{M}$ $\mathrm{Zn}$ ) and PW supplemented with $25 \mu \mathrm{M} \mathrm{ZnSO}$, colony fringe widths were similar for each strain (Fig. 4), with an average of $49 \pm 3 \mu \mathrm{m}$ for the WT strain, $29 \pm 2 \mu \mathrm{m}$ for $z u r$, and $23 \pm 4 \mu \mathrm{m}$ for $c z c D$. When PW was supplemented with $100 \mu \mathrm{M} \mathrm{ZnSO}_{4}$, all strains showed reduced colony fringe width compared with plain PW or PW supplemented with $25 \mu \mathrm{M} \mathrm{ZnSO}_{4}$. In this medium, the colony fringe width of the WT colonies was $18 \pm 4 \mu \mathrm{m}$, whereas the fringe widths of $z u r$ and $c z c D$ colonies were $6 \pm 3 \mu \mathrm{m}$ and $5 \pm 2 \mu \mathrm{m}$, respectively.

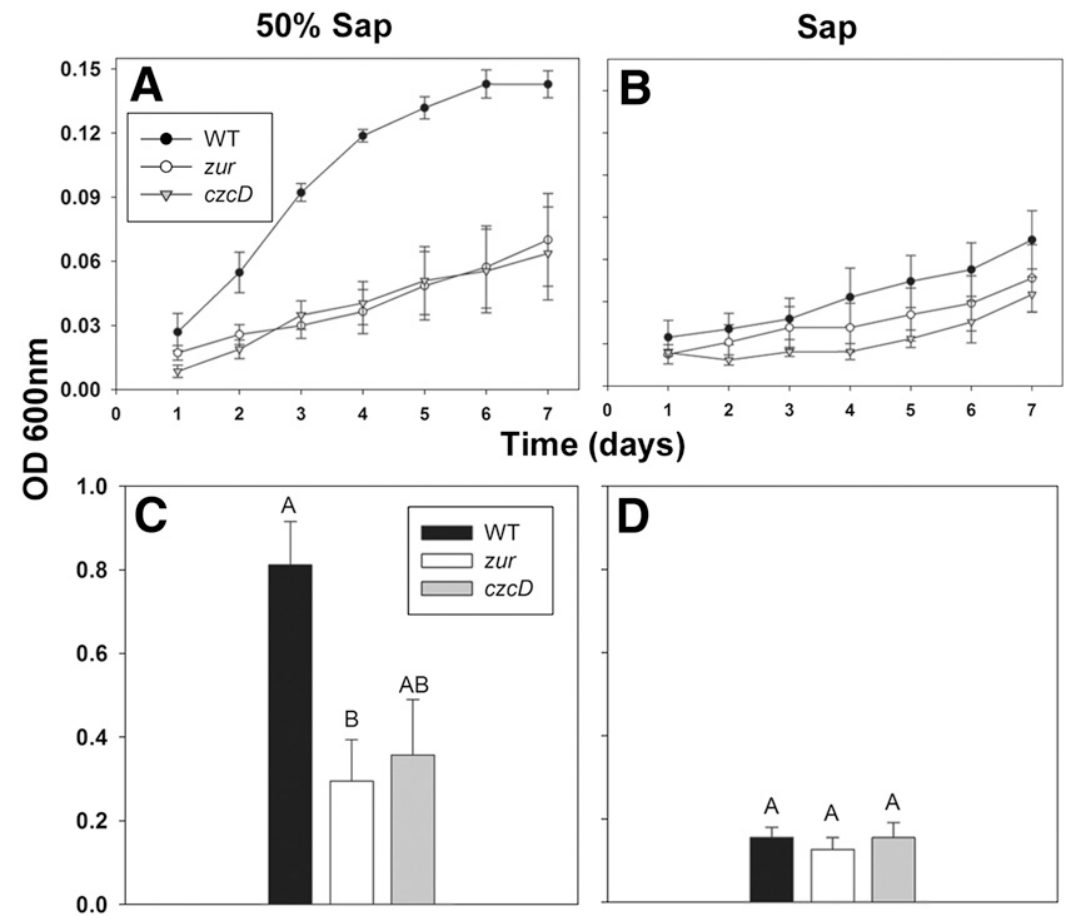

Fig. 2. Growth and biofilm production of Xylella fastidiosa strains in media containing grapevine xylem sap. Growth curves of wild-type (WT), zur, and $c z c D$ strains grown in A, $50 \%$ and $\mathbf{B}, 100 \%$ sap for 7 days. Biofilm production of WT, zur, and $c z c D$ strains grown in $\mathbf{C}, 50 \%$ and $\mathbf{D}, 100 \%$ sap for 7 days. Different letters indicate statistical differences $(P<0.05)$ according to analysis of variance and least significant difference test. Each data point represents mean \pm standard error of the mean $(n=6)$. Data presented were obtained from four independent experiments. 


\section{Gene expression in the $z u r$ and $c z c D$ mutants.}

Because zur and $c z c D$ regulate intracellular $\mathrm{Zn}$ concentrations which, in turn, can affect several cellular traits, the expression of several virulence-related genes in the two mutants was compared with their expression in the WT by quantitative reversetranscription polymerase chain reaction (qRT-PCR) in cells grown on PW agar plates supplemented with $25 \mu \mathrm{M} \mathrm{ZnSO}_{4}$. Genes evaluated are involved in twitching motility ( pilT), polysaccharide degradation ( $p g l A$ ), a putative $\mathrm{Zn}$ metalloprotease (PD1853), attachment ( $h x f A)$, EPS production (xanB and gumD), iron-heme transport (ton $B)$, amino acid acquisition (potE), detoxification of reactive oxygen species ( $\operatorname{sod} M)$, and detoxification of $\mathrm{Zn}(c z c D)$. Both the zur and $c z c D$ mutants showed a significant decrease in the expression of pilT $(P=$ 0.007 and 0.016 , respectively) and gumD $(P=0.009$ and 0.010, respectively) compared with the WT (Fig. 5). The zur mutant showed a slightly significant increase in the expression of pglA $(P=0.046)$ and pot $E(P=0.036)$ compared with the WT (Fig. 5). Expression of the other analyzed genes was not modified in the mutants compared with the WT.

\section{Virulence of zur and $c z c D$ mutants in tobacco.}

The virulence of $z u r$ and $c z c D$ mutants was tested by needle inoculation of tobacco plants grown in the greenhouse. Foliar
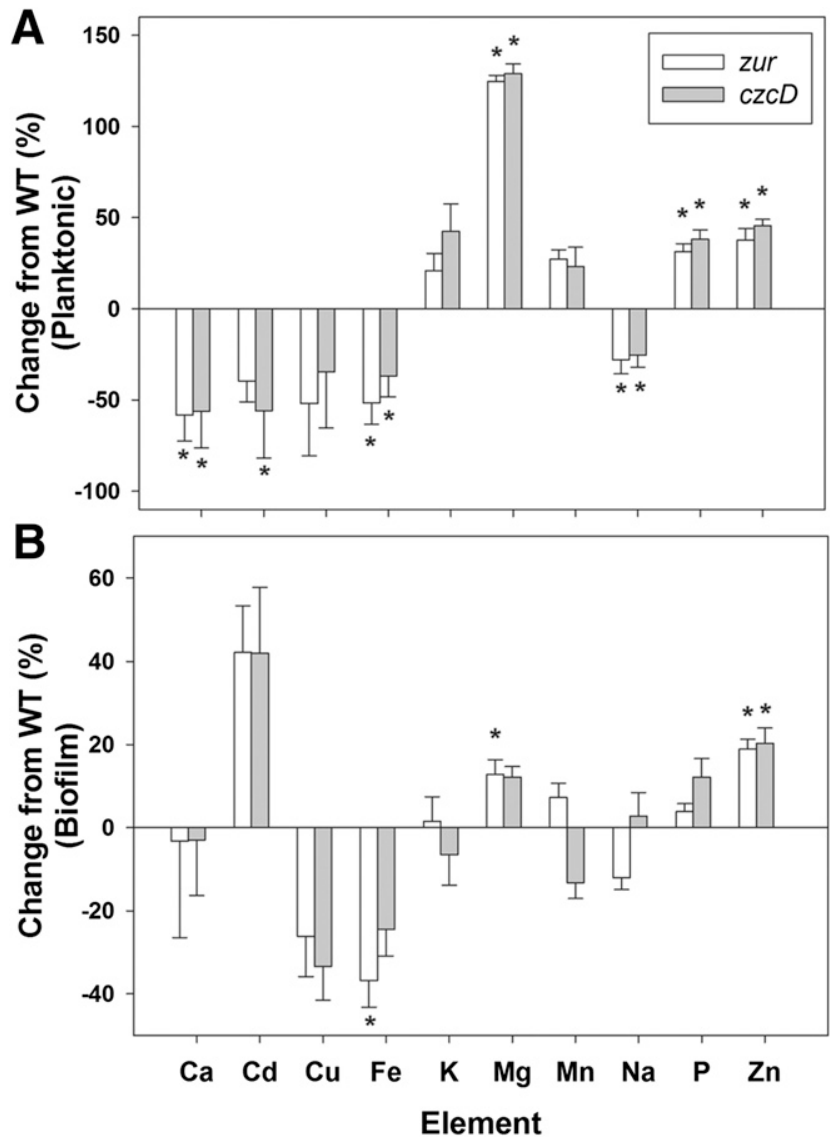

Fig. 3. Ionomic changes in Xylella fastidiosa mutant cells compared with wild-type (WT) cells after Zn shock. X. fastidiosa WT, zur, and $c z c D$ were grown in PD2 for 3 days. Media were then supplemented with $100 \mu \mathrm{M}$ $\mathrm{ZnSO}_{4}$, cultures were incubated overnight, and the ionome was measured by inductively coupled plasma with optical emission spectrometry (mol element/mol S). Data are expressed as percent change from the WT. A, Planktonic cells; B, biofilm cells. Each data point represents mean \pm standard error of the mean $(n=5)$; * indicates significant difference from the WT according to analysis of variance and Tukey's highly significant difference test $(P<0.05)$. Data presented were obtained from two independent experiments. symptoms, which included chlorosis and marginal leaf scorching, were rated during onset of symptoms (60 and 80 dpi in two independent experiments). Plants inoculated with either mutant strain showed reduced symptom development compared with plants inoculated with the WT $(P<0.05)$. Leaf scorch symptoms were reduced $91 \%$ in the zur-inoculated plants and $100 \%$ (not detected) in $c z c D$-inoculated plants compared with the WT (Fig. 6A). Leaf chlorosis was reduced 81 and $58 \%$ in zur- and $c z c D$-inoculated plants, respectively (Fig. 6A).

Bacterial populations were assessed when foliar symptoms were evident (60 and 80 dpi in two independent experiments) by qPCR of three leaf-petioles per plant (collected one, four, and seven internodes above the highest inoculated leaf). For all the strains, $100 \%$ of the inoculated plants were colonized by $X$. fastidiosa as detected by qPCR. At any given position above the inoculation point, the WT strain reached significantly higher population levels than either of the mutants $(P<0.05)$. The only exception was the population of $c z c D$ at the fourth internode above the inoculation point, which was not significantly different from that of the WT. Populations of the WT strain were $3.80 \pm$ $0.07,3.80 \pm 0.09$, and $3.87 \pm 0.17 \log \mathrm{CFU} / \mathrm{mg}$ at one, four, and seven internodes from the inoculation point, respectively (Fig. 6B). zur/czcD populations were $2.98 \pm 0.3 / 3.2 \pm 0.21$, $2.45 \pm 0.43 / 3.04 \pm 0.23$, and $2.64 \pm 0.24 / 2.61 \pm 0.35$ at one, four, and seven internodes above the inoculation point, respectively.

\section{Ionomic changes of plants inoculated with WT, zur, and $c z c D$ mutant strains.}

The ionome of leaves collected one and four internodes above the highest inoculated leaf was analyzed at the time of symptom appearance. Percent change from the bufferinoculated (control) plants was used as an indication of the physiological status of the whole plant to assess the effects of bacterial infection on the host (Baxter et al. 2008; De La Fuente et al. 2013). Under our experimental conditions, 11 elements (boron [B], Ca, Cd, Fe, potassium [K], Mg, Na, Ni, P, sulfur [S], and $\mathrm{Zn}$ ) were reliably detected in leaves across all experiments. Significant changes in the mineral content of $X$. fastidiosainoculated plants with respect to the buffer-inoculated plants were observed for $\mathrm{B}, \mathrm{Ca}, \mathrm{K}, \mathrm{Mg}, \mathrm{Na}, \mathrm{Ni}$, and $\mathrm{S}(P<0.05)$. Plants inoculated with the WT strain showed the greatest modification of the leaf ionome, with significant increases in $\mathrm{B}$ (34 $\pm 18 \%), \mathrm{Ca}(38 \pm 7 \%), \mathrm{Mg}(29 \pm 6 \%), \mathrm{Na}(49 \pm 12 \%), \mathrm{Ni}$ $(28 \pm 6 \%)$, and $S(49 \pm 11 \%)$ with respect to the bufferinoculated plants (Fig. 7). Plants inoculated with $c z c D$ only showed increased levels of $\mathrm{Mg}(29 \pm 5 \%)$ and $\mathrm{S}(36 \pm 9 \%)$ and decreased levels of $\mathrm{K}(-33 \pm 7 \%)$. Plants inoculated with zur had no significant changes compared with buffer-inoculated plants (Fig. 7).

\section{DISCUSSION}

In the present study, it was demonstrated that detoxification of $\mathrm{Zn}$ is an important virulence factor for $X$. fastidiosa and it is required for efficient colonization of the host. Interestingly, $\mathrm{Zn}$ detoxification was only previously demonstrated to be an important virulence factor in bacteria that infect metal hyperaccumulator plants (Fones et al. 2010) but the $X$. fastidiosa hosts examined here (tobacco and grape-by proxy of sap) are not know to be hyperaccumulators. In Xanthomonas campestris pv. campestris, a mutation in zur led to reduced $\mathrm{Zn}$ tolerance, but that mutant could still tolerate $\mathrm{Zn}$ levels much higher than those found in the plant host (Tang et al. 2005). Here, the minimum $\mathrm{Zn}$ concentration that had an inhibitory effect on growth of both mutants $(25 \mu \mathrm{M})$ closely matched that found in tobacco xylem sap (20 $\mu \mathrm{M})$ (Oliver et al. 2014)], indicating that 
Xylella fastidiosa needs to detoxify the $\mathrm{Zn}$ levels present in planta in order to colonize its host successfully. Accordingly, the $X$. fastidiosa zur and $c z c D$ mutants analyzed here were impaired in their ability to tolerate grapevine xylem sap in the growth medium, where the final $\mathrm{Zn}$ concentration was also approximately $20 \mu \mathrm{M}$ (in $50 \%$ sap, the $\mathrm{Zn}$ concentration in pure grapevine xylem sap was $39 \mu \mathrm{M}$ ). In addition, it was shown here that changes in the plant leaf ionome caused by virulent $X$. fastidiosa strains (Oliver et al. 2014) were absent or reduced when $\mathrm{Zn}$ homeostasis mutants were inoculated in tobacco plants, further demonstrating that, in this system, host leaf ionome modification is an indicator of bacterial virulence.

The bacterial ionome characterization presented here shows that both mutants have increased intracellular $\mathrm{Zn}$ accumulation, confirming that $z u r$ and $c z c D$ are involved in $\mathrm{Zn}$ efflux in $X$. fastidiosa. In addition, this suggests that the increased sensitivity to this metal is due to its increased and presumably toxic intracellular accumulation. In addition to $\mathrm{Zn}$, differential accumulation of other elements was detected. In both mutants, planktonic cell content of Fe was significantly decreased and $\mathrm{Mg}$ was significantly increased compared with the WT. These tendencies were also observed in biofilm cells of both mutants but were significant only for zur. The fact that biofilm cells are embedded in a polysaccharide matrix likely protected them from changes in the media; therefore, only a few ionomic changes were significant. If all these changes in element accumulation also occur in planta (which is technically challenging to test), they could contribute to the observed reduction in virulence. Fe may be particularly relevant, because this element transcriptionally regulates genes involved in $X$. fastidiosa virulence (Zaini et al. 2008). Mg was also shown to affect virulence in bacterial pathogens (De La Fuente et al. 2014), although it does not affect biofilm formation (Cruz et al. 2012) or movement (Cruz et al. 2014) in X. fastidiosa. Decreased Ca content, only significant in planktonic cells, can also cause a reduction in virulence according to our previous studies in $X$. fastidiosa (Cruz et al. 2012). Although difficult to interpret, similar crosstalk has been previously observed in the regulation of metal ions in response to alterations in $\mathrm{Zn}$ homeostasis at the transcriptional level (Ciavardelli et al. 2011; Lee et al. 2005; Ogasawara et al. 2012; Park and Ely 2008). The biological significance of the observed bacterial ionomic changes in this

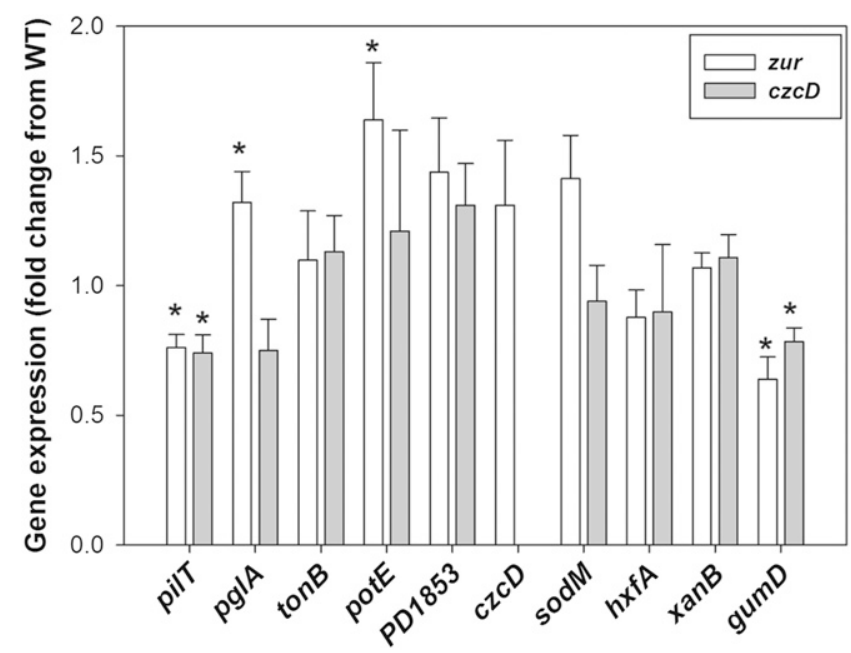

Fig. 5. Expression of virulence-related genes in $z u r$ and $c z c D$ mutant strains compared with the wild type (WT). WT, zur, and $c z c D$ strains were grown on PW agar plates supplemented with $25 \mu \mathrm{M} \mathrm{ZnSO}_{4}$ for 7 days. Fold change in gene expression with respect to the WT was evaluated by quantitative reverse-transcription polymerase chain reaction according to the $2^{-\Delta \Delta C T}$ method; * indicates significant difference from the WT according to one-sample $t$-test (fold change $\neq 1, P<0.05$ ). Each data point represents mean \pm standard error of the mean $(n=6)$ obtained from two independent experiments.
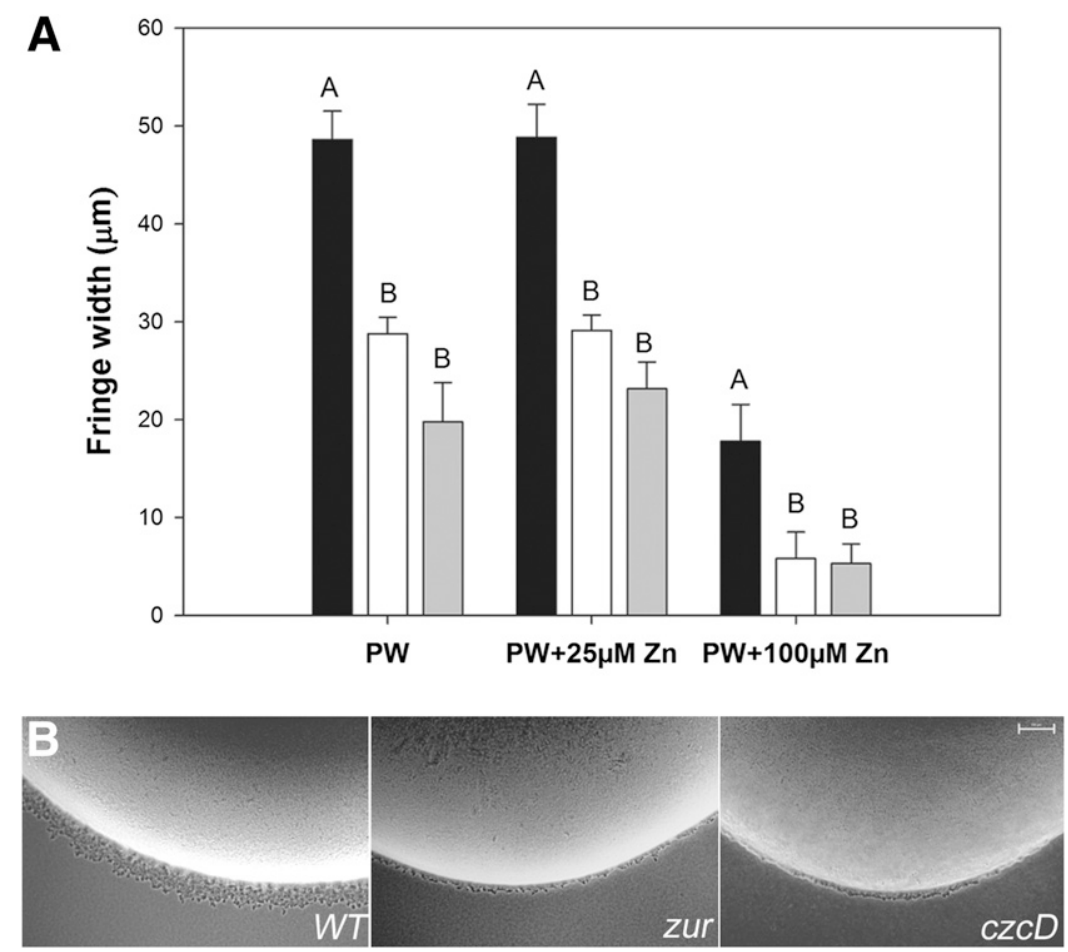

Fig. 4. Twitching motility of Xylella fastidiosa strains. A, Colony fringe width of wild-type (WT), zur, and $c z c D$ strains grown on PW agar plates and PW supplemented with 25 or $100 \mu \mathrm{M} \mathrm{ZnSO}_{4}$. Different letters indicate statistical differences according to analysis of variance and least significant difference $(P<$ $0.05)$. Each data point represents mean \pm standard error of the mean $(n=5)$. Data presented were obtained from two independent experiments. B, $X$. fastidiosa colonies with peripheral fringes on PW agar plates. The bar at the right represents $100 \mu \mathrm{m}$. 
study in response to $\mathrm{Zn}$ is not clear; nevertheless, these ionomic changes show that increased accumulation of $\mathrm{Zn}$ affects the overall metal homeostasis and physiology of X. fastidiosa.

Increased $\mathrm{Zn}$ accumulation in both mutants was correlated with reduced expression of pilT (which codes for an ATPase that promotes twitching motility by retracting type IV pili) (Mattick 2002) and reduced colony fringe width in vitro. This explains the observation from our previous study that addition of $\mathrm{Zn}$ to the growth medium reduced twitching motility of $X$. fastidiosa in liquid culture in microfluidic chambers (Navarrete and De La Fuente 2014) and is, to the best of our knowledge, the first demonstration of the regulation of twitching motility by $\mathrm{Zn}$. The observed reduction in colony fringe of both mutant strains, even without the addition of $\mathrm{Zn}$ ( $\mathrm{Zn}$ concentration in PW was $3.0 \mu \mathrm{M}$ ), may indicate that very low levels of $\mathrm{Zn}$ are enough to inhibit twitching motility. Accumulation of $\mathrm{Zn}$ also led to a reduction in the expression of $g u m D$, which is involved in the synthesis of EPS (da Silva et al. 2001; Killiny et al. 2013). This is in contrast with our previous results (Navarrete and De La Fuente 2014), in which we observed that $\mathrm{Zn}$ induced the synthesis of EPS; however, those observations were performed at a much higher $\mathrm{Zn}$ concentration $(400 \mu \mathrm{M})$, which is associated with a generalized stress response and possibly induces the viable but not culturable state in X. fastidiosa. It is important to note that both PilT and GumD have enzymatic activity; thus, a subtle reduction in their expression at the mRNA level may have a more pronounced effect on the observed phenotype (twitching motility and EPS production, respectively). Additionally, we cannot rule out the possibility that $\mathrm{Zn}$ represses the expression of these genes at the posttranscriptional level.

At high $\mathrm{Zn}$ concentrations, Zur is known to bind the promoter region of the znuABC Zn-uptake system to repress its transcription (Patzer and Hantke 1998), and to bind to the promoter of $c z c D$ to promote its transcription (Huang et al. 2008). Additionally, zur regulates the expression of genes involved in $\mathrm{Fe}$ uptake (tonB and ton $B$-dependent receptors), bacteriocin production, and oxidative stress resistance (He et al. 2007). Regulation of virulence by zur has been observed in several bacteria previously. Deletion of zur causes reduction in virulence in the animal pathogens Salmonella Typhimurium and $P$. aeruginosa (Campoy et al. 2002; Wang et al. 1996). In Xanthomonas campestris pv. campestris and X. oryzae pv. oryzae, bacterial species closely related to $X$. fastidiosa, mutations in zur caused reductions in virulence (Tang et al. 2005; Yang et al. 2007), which were attributed to a reduction in EPS production (Tang et al. 2005) or reductions in both EPS production and tolerance to oxidative stress (Yang et al. 2007). Here, it was found that the zur mutant upregulates pglA (polygalacturonase), an enzyme used to degrade pit membranes so that the bacterium can move laterally in the xylem (Roper et al. 2007), and potE, involved in amino acid acquisition. These effects may be a response to stress caused by excess $\mathrm{Zn}$ but it is not clear whether these responses have an effect on bacterial growth or virulence. All of the previously mentioned traits, which are known to be regulated by zur in other bacteria, are important for virulence in

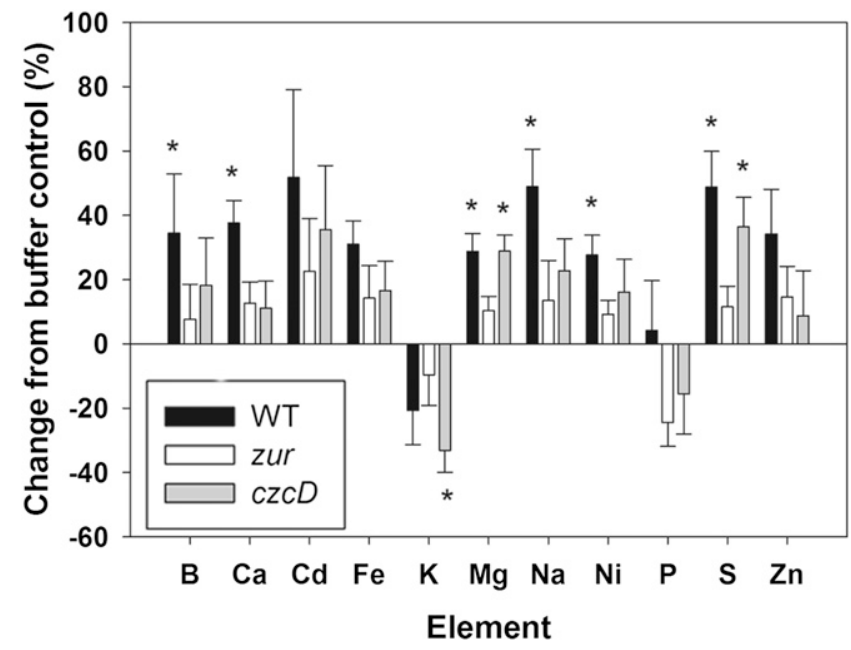

Fig. 7. Changes in leaf ionome of Xylella fastidiosa-inoculated tobacco. Plants were needle inoculated with $X$. fastidios $a$ wild type (WT), zur, $c z c D$, or buffer (control) and maintained in the greenhouse until symptom onset. The ionome of leaves localized one and four internodes above the inoculation point was characterized by inductively coupled plasma with optical emission spectrometry ( $\mathrm{mg}$ element/g of plant tissue). Data are expressed here as a percent change from the buffer-inoculated control. Each data point represents mean \pm standard error $(n=5)$; * indicates significant difference from the buffer control according to analysis of variance and Tukey's highly significant difference test $(P<0.05)$. Data presented were obtained from two independent experiments.
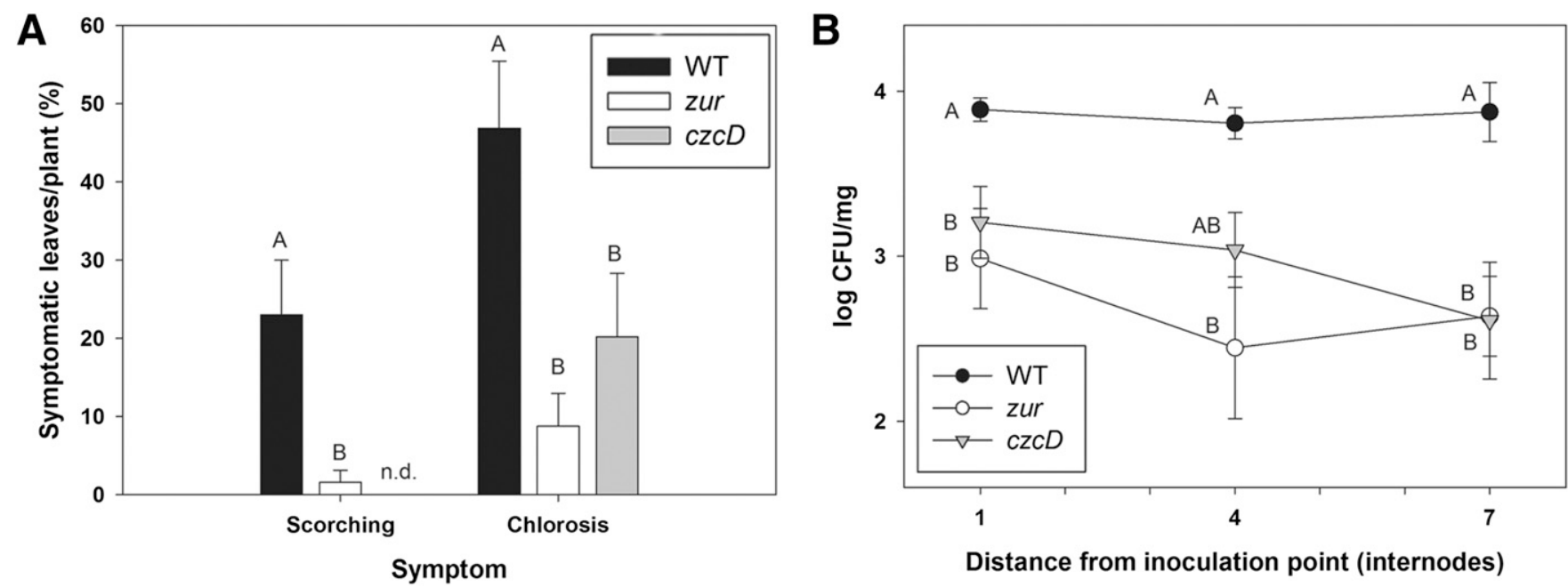

Fig. 6. Virulence of Xylella fastidiosa strains in tobacco. A, Symptom quantification of plants mechanically inoculated with X. fastidiosa (scored at symptom onset). B, Bacterial populations (log CFU/mg of fresh weight) at the time of symptom appearance by distance from inoculation point. Different letters indicate statistical differences according to analysis of variance and least significant difference $(P<0.05)$; n.d. $=$ not detected. In $\mathrm{B}$, different letters indicate significant differences for the same internode. Each data point represents mean \pm standard error of the mean $(n=5)$. Data presented were obtained from two independent experiments. 
$X$. fastidiosa. Bacteriocin production (Simpson et al. 2000), tolerance to oxidative stress (Matsumoto et al. 2009), and tonB activity (Cursino et al. 2009) are required for full virulence in this bacterium. Under our experimental conditions, the ton $B$ homolog chosen for gene expression analysis showed no alteration in its expression in the zur mutant, indicating that it is not transcriptionally regulated by zur. However, X. fastidiosa has five other $\operatorname{ton} B$ homologs in its genome; thus, we cannot rule out that at least one of these homologs is regulated by zur. The regulatory nature of zur may also explain why this mutant has increased biofilm production compared with the WT, despite the fact that $\mathrm{Zn}$ supplementation reduces biofilm production (Cobine et al. 2013). This effect might be related to production of adhesins other than hxfA. In Streptococcus pneumoniae, AdcR, the $\mathrm{Zn}$ transcriptional regulator in this bacterial group, controls the expression of adhesins required for adherence to the respiratory mucosa of the host (Elsner et al. 2002; Panina et al. 2003; Shafeeq et al. 2011). Further assessment of zur mutant adherence characteristics and a comparative transcriptomic analysis of this mutant versus the WT will help explain its increased biofilm production as well as the reduced virulence observed on tobacco.

$c z c D$ was shown here for the first time, to the best of our knowledge, to be implicated in host plant-pathogen interactions. $c z c D$ was previously known, however, to be upregulated during infection of host cells by Brucella melitensis (Rossetti et al. 2011). In Xanthomonas campestris pv. campestris, a knockout in this gene was constructed that showed increased sensitivity to $\mathrm{Zn}$ but its virulence was not tested; despite that, expression of $c z c D$ was shown to be controlled by zur (Huang et al. 2008). Conversely, we did not find that to be the case for Xylella fastidiosa under our experimental conditions, which may be due to the $\mathrm{Zn}$ concentration used in our experiment or simply because regulation of $c z c D$ in this bacterium differs from that in Xanthomonas campestris pv. campestris.

Ionomic studies in plants provide an opportunity to assess their overall physiological response to an environmental stimulus. Because the leaf ionome is affected by several processes, from mineral absorption in the roots to transpiration in the stomata, changes in the ionome could be used as indices of a physiological alteration (Baxter et al. 2008; Salt et al. 2008). Infection with Xylella fastidiosa induces a physiological modification in the host that affects its ionome. In fact, modifications in the leaf ionome have been shown to be induced in several hosts infected with X. fastidiosa (De La Fuente et al. 2013; Oliver et al. 2014), and these changes correlate with bacterial virulence (Oliver et al. 2014). In contrast, populations in leaf petioles have been shown not to correlate with virulence (Gambetta et al. 2007; Oliver et al. 2014). Furthermore, bacterial strains that show relatively lower populations in planta can induce the highest levels of symptom incidence and host leaf ionome modification (Oliver et al. 2014). Thus we hypothesized that, if the virulence of our mutant strains was reduced, modifications in the host leaf ionome would be reduced too. We compared modifications of the tobacco leaf ionome induced by the $X$. fastidiosa WT to those produced by the zur and $c z c D$ mutants. A reduced or absent alteration of the ionome was observed in plants inoculated with either of the mutants, despite the fact that populations of both mutants were only slightly reduced compared with the WT (a difference of 0.5 to $1.5 \log \mathrm{CFU} / \mathrm{mg}$, depending on the internode position). Plants inoculated with zur showed no changes in leaf ionome compared with buffer-inoculated plants, whereas those inoculated with $c z c D$ had only an increased accumulation of $\mathrm{Mg}$ and $\mathrm{S}$ but not of $\mathrm{Ca}$, and a reduced accumulation of $\mathrm{K}$, further demonstrating that the virulence of these mutants is compromised and suggesting that $\mathrm{Ca}$ is only increased in plants infected with strains with WT levels of virulence. In this way, inoculating tobacco with $X$. fastidiosa mutants affected in different virulence traits could help elucidate which traits are necessary to induce ionomic changes in the host.

Modification of the host ionome in a virulence-dependent manner is not restricted to the interactions of X. fastidiosa with its plant hosts. Recently, it was found that Stenotrophomonas maltophilia, a bacterium in the family Xanthomonadeaceae associated with cystic fibrosis in humans, modifies the host lung ionome in a virulence-dependent fashion (Pompilio et al. 2014), suggesting that this phenomenon could be widespread. It would be interesting, then, to apply ionomic studies to other pathosystems, which may suggest chemical markers of infection (convenient when the distribution of the pathogen is patchy, there is a long incubation period, or symptom appearance is erratic) and management strategies.

In summary, this research shows that $\mathrm{Zn}$ detoxification is an important virulence strategy for $X$. fastidiosa, a bacterium that infects nonhyperaccumulator plants, suggesting that this metal, at the levels present in the host plant, constitutes a preformed defense that limits the growth of $X$. fastidiosa and may have an influence on the appearance of symptoms. This suggests that the concept of elemental defense could be extended to nonhyperaccumulator plants. In addition, we showed that bacterial strains with reduced virulence to tobacco are impaired in inducing a leaf-ionome modification, indicating that the host plant is less affected by these strains. The work presented here reinforces the important role that mineral elements have in $X$. fastidiosa-host interactions and suggests that the mineral status of the host plant could be used to assess its physiological status or even be manipulated as a disease management strategy.

\section{MATERIALS AND METHODS}

\section{Bacterial strains and culture conditions.}

$X$. fastidiosa strain Temecula was used as the WT strain in all experiments. Bacterial stocks were stored in PD2 (Davis et al. 1981 b) broth with $20 \%$ glycerol at $-80^{\circ} \mathrm{C}$. All strains were grown on PW agar (Davis et al. 1980) with or without kanamycin $(\mathrm{Km})(30 \mu \mathrm{g} / \mathrm{ml})$.

\section{Construction of mutant strains.}

Homologous recombination was used to generate $X$. fastidiosa zur (PD1849) and $c z c D$ (PD1811) null mutants, and fusion PCR was used to construct the knockout vectors. First, $X$. fastidiosa WT genomic DNA was extracted using a modified cetyltrimethylammonium bromide (CTAB) protocol (Doyle and Doyle 1987). For the construction of the zur knockout vector, PCR was performed to amplify approximately 750 bp upstream and downstream of the zur coding region. All PCR reactions were conducted using the Phusion High-Fidelity PCR Kit (New England Biolabs, Ipswich, MA, U.S.A.), following manufacturer's instructions. Primers (Supplementary Table S1) were designed using Primer3 (Untergrasser et al. 2012). The upstream and downstream fragments flanking the zur coding region were amplified using primers ZUPF/ZUPR (upstream) or ZDOF/ ZDOR (downstream). ZUPR and ZDOF contain AscI restriction sites, which are needed for subsequent insertion of a Km cassette (see below). PCR was performed using the following parameters: $98^{\circ} \mathrm{C}$ for $10 \mathrm{~s}$; followed by 35 cycles of $98^{\circ} \mathrm{C}$ for $10 \mathrm{~s}, 65^{\circ} \mathrm{C}$ for $30 \mathrm{~s}$, and $72^{\circ} \mathrm{C}$ for $1 \mathrm{~min}$; and a final extension step of $72^{\circ} \mathrm{C}$ for $5 \mathrm{~min}$. The amplified segments were visualized by gel electrophoresis. PCR products were purified using the PCR Extract Mini Kit (5 PRIME, Gaithersburg, MD, U.S.A.), according to manufacturer's instructions. Subsequently, the previously purified PCR products (1 ng each) were used as templates for fusion PCR using primers ZIF/ZIR. PCR was performed using the following parameters: $98^{\circ} \mathrm{C}$ for $10 \mathrm{~s}$; followed by 35 cycles 
of $98^{\circ} \mathrm{C}$ for $10 \mathrm{~s}, 65^{\circ} \mathrm{C}$ for $30 \mathrm{~s}$, and $72^{\circ} \mathrm{C}$ for $2 \mathrm{~min}$; and a final extension step of $72^{\circ} \mathrm{C}$ for $5 \mathrm{~min}$. The amplified segments were visualized by gel electrophoresis and the fusion product $(1.2$ kbp) was gel purified using the Agarose GelExtract Mini Kit (5 PRIME), according to the manufacturer's instructions. The purified product was then cloned into a pJET1.2/blunt cloning vector (Thermo Fisher Scientific, Pittsburgh), following the manufacturer's instructions. The resulting plasmid, pJET_zur, was transformed into Escherichia coli NEB 5- $\alpha$ (New England Biolabs), and positive clones were selected in Luria-Bertani (LB) broth with ampicillin $(100 \mu \mathrm{g} / \mathrm{ml})$. A Km cassette was amplified from pUC4K with primers containing the AscI restriction site sequence and cloned into pJET1.2 to produce pJET_kan. pJET_kan was transformed into E. coli NEB 5- $\alpha$, and positive clones were selected in LB broth with $\mathrm{Km}(50 \mu \mathrm{g} / \mathrm{ml})$. pJET_zur and pJET_kan were digested with AscI.pJET_zur was dephosphorylated with shrimp alkaline phosphatase (Affymetrix, USB, Santa Clara, CA, U.S.A.) for $1 \mathrm{~h}$ at $37^{\circ} \mathrm{C}$ followed by 15 min at $65^{\circ} \mathrm{C}$. pJET_zur and the Km cassette released from the pJET_kan AscI digestion were then ligated with T4 ligase to create pJET_zur_kan (3 $\mathrm{h}$ at room temperature).

The $c z c D$ knockout vector, pJET_czcD_kan, was constructed as described above for pJET_zur_kan using the primers CUPF/ CUPR and CDOF/CDOR for amplification of the upstream and downstream segments of the $c z c D$ coding region, respectively. Fusion PCR was conducted using the primers CIF/CIR.

pJET_zur_kan and pJET_czcD_kan were electroporated into E. coli EAM1, which expresses a $X$. fastidiosa methyltransferase (PD_1607) (Matsumoto and Igo 2010), in a 2-mm cuvette (Eppendorf, Hauppauge, NY, U.S.A.) at $2.4 \mathrm{kV}$ for $5.7 \mathrm{~ms}$. Positive clones were selected from LB agar plates containing ampicillin $(100 \mu \mathrm{g} / \mathrm{ml})$ and $\mathrm{Km}(50 \mu \mathrm{g} / \mathrm{ml})$ incubated overnight at $37^{\circ} \mathrm{C}$. For methylation of pJET_zur_kan and pJET_czcD_kan plasmids, $E$. coli EAM1 cells containing the corresponding plasmids were grown at $37^{\circ} \mathrm{C}$ and $200 \mathrm{rpm}$ overnight in LB containing isopropylthio-galactopyranoside $(1 \mathrm{mM})$, ampicillin $(100 \mu \mathrm{g} / \mathrm{ml})$, and $\mathrm{Km}$ $(50 \mu \mathrm{g} / \mathrm{ml})$. Plasmid DNA was extracted using the GeneJET Plasmid Miniprep Kit (Thermo Scientific).

Electrocompetent $X$. fastidiosa Temecula WT cells were prepared as previously described (Matsumoto et al. 2009). An electrocompetent $X$. fastidiosa suspension $(50 \mu \mathrm{l})$ and $200 \mathrm{ng}$ of methylated plasmid DNA were transferred to a 2-mm cuvette on ice (Eppendorf) and electroporated at $2.5 \mathrm{kV}$ for $5.7 \mathrm{~ms}$. Immediately, $1 \mathrm{ml}$ of PD3 medium (Davis et al. 1981a) was added to the transformed cells, which were incubated at $28^{\circ} \mathrm{C}$ and $150 \mathrm{rpm}$ overnight. The culture $(200 \mu \mathrm{l})$ was then spread plated on PD3G solid media (Davis et al. 1981b) (solidified with Gelrite instead of agar) containing $\mathrm{Km}$ at $30 \mu \mathrm{g} \mathrm{ml}^{-1}$. Plates were incubated at $28^{\circ} \mathrm{C}$ until transformants were visible (approximately 10 to 15 days). To confirm the mutations, DNA was extracted from resulting transformants using the previously mentioned CTAB protocol, PCR amplified with primers designed to bind the regions flanking the recombination region (ZchUPF, ZchDOWNR or CchUPF, CchDOWNR) paired with primers designed to bind the Km cassette (ZchUPR, ZchDOWNF or CchUPR, CchDOWNF), and sequenced (Eurofins MWG Operon, Huntsville, AL, U.S.A.). Sequences were BLASTed against the $X$. fastidiosa Temecula genome (GenBank) to confirm the correct insertion of the $\mathrm{Km}$ cassette and the absence of any sequence mismatches. Additionally, primers were designed to amplify an internal 400-bp region of $z u r$ (ZkoF/ZkoR) or $c z c D$ (CkoF/CkoR) coding regions. In this screening, gene deletions yielded negative PCR amplifications.

\section{Grapevine xylem sap collection.}

Xylem sap fluid from grapevines (Vitis vinifera 'Chardonnay') was collected by bleeding pruned vines in the spring of 2012 from a vineyard in Dahlonega, GA. Collected sap was filter sterilized $(0.2 \mu \mathrm{m})$ and stored at $-80^{\circ} \mathrm{C}$.

Bacterial growth in media with different $\mathrm{Zn}$ concentrations.

Growth curves were obtained for X. fastidiosa WT, zur, and $c z c D$ grown in 96-well plates containing $200 \mu$ of different media: PD2, PD2 + Zn (amended to 25, 100, and $400 \mu \mathrm{M}$ $\mathrm{ZnSO}_{4}$ ), 50\% sap (1:1 PD2/sap, vol/vol), and $100 \%$ sap (pure xylem sap). Seven-day-old $X$. fastidiosa cells collected from $\mathrm{PW}$ or $\mathrm{PW}+\mathrm{Km}$ solid media were used to inoculate wells containing media to an initial $\mathrm{OD}_{600}$ of 0.01 . Plates were incubated at $28^{\circ} \mathrm{C}$ and $150 \mathrm{rpm}$ for 7 days. $\mathrm{OD}_{600}$ was recorded daily with six replicates for each strain-medium combination. On day seven, biofilm growth was evaluated by the crystal violet assay, as described previously (Zaini et al. 2009). Briefly, after planktonic growth was recorded, the remaining broth was removed and the plates were gently rinsed with distilled water twice. Biofilms were stained with $240 \mu \mathrm{l}$ of $0.1 \%$ crystal violet for $20 \mathrm{~min}$. Plates were rinsed with distilled water as above, $240 \mu \mathrm{l}$ of $6: 4$ acetone/ethanol ( $\mathrm{vol} / \mathrm{vol})$ was added, and the plates were agitated at $150 \mathrm{rpm}$ for $5 \mathrm{~min}$. The $\mathrm{OD}_{600}$ of the resulting solution was the recorded. Five (media supplemented with $\mathrm{ZnSO}_{4}$ ) or four (media supplemented with sap) independent experiments were performed.

\section{Bacterial ionomic changes in response to high $\mathrm{Zn}$ levels.}

For measurement of $X$. fastidiosa intracellular $\mathrm{Zn}$ content, 7-day-old $X$. fastidiosa WT, zur, and $c z c D$ cells were collected from PW or PW + Km solid media and used to inoculate 250-ml flasks containing $50 \mathrm{ml}$ of PD2 to an initial $\mathrm{OD}_{600}$ of 0.01 , with five replicate flasks per strain. Flasks were incubated at $28^{\circ} \mathrm{C}$ and $150 \mathrm{rpm}$ for 3 days. The $\mathrm{ZnSO}_{4}$ concentration of the broth was adjusted to $100 \mu \mathrm{M}$ and the flasks were further incubated overnight. Planktonic cells were harvested by centrifuging $40 \mathrm{ml}$ of the broth at $3,200 \times g$ for $40 \mathrm{~min}$. Only $40 \mathrm{ml}$ were used in order to avoid cell aggregates present in the bottom of the flasks. Cells were washed twice with $8 \mathrm{ml}$ of moleculargrade water and once with $2 \mathrm{ml}$ of $0.5 \mathrm{mM}$ EDTA to remove externally bound metal ions. Biofilms were resuspended in $5 \mathrm{ml}$ of molecular-grade water and washed as with the planktonic cells. The final cell pellets were digested for $1 \mathrm{~h}$ at $100^{\circ} \mathrm{C}$ in $200 \mu \mathrm{l}$ of mineral-free concentrated nitric acid (OPTIMA; Fisher Scientific). After dilution with ultrapure, mineral-free water and centrifugation at $13,000 \times g$ to remove any remaining particulates, samples were analyzed by ICP-OES (7,100 DV; Perkin-Elmer, Waltham, MA, U.S.A.) as described by Cobine and associates (2013), with simultaneous measurements of B, $\mathrm{Ca}, \mathrm{Cd}, \mathrm{Cu}$, cobalt (Co), Fe, K, Mg, Mn, Na, Ni, S, and Zn. As controls, blanks of nitric acid were digested in parallel. Metal concentrations were determined by comparing intensities to a standard curve created from certified metal standards (SPEX CertiPrep, Metuchen, NJ, U.S.A.). Results were expressed using $\mathrm{S}$ measurements as internal denominators representing the amount of cells present in the samples. Three independent experiments were performed.

\section{Evaluation of twitching motility on agar plates.}

Twitching motility was assessed on PW agar plates with different levels of $\mathrm{ZnSO}_{4}$ supplementation $(25$ and $100 \mu \mathrm{M})$. Cells of the WT, zur, and $c z c D$ strains were grown for 7 days in PW agar or PW agar plus Km, scraped, spotted in PW agar with or without $\mathrm{Zn}$ supplementation with five replicates per strain-medium combination, and incubated for 3 days at $28^{\circ} \mathrm{C}$. The colony fringe width was measured under the microscope. Image acquisition was done using a Nikon DS-Q1 digital camera (Nikon, Melville, NY, U.S.A.) controlled by NIS Elements software (version 3.0; Nikon). Two independent experiments were performed. 


\section{Analysis of gene expression by qRT-PCR.}

The expression of the following genes was analyzed by qRTPCR: pglA (PD1485), pilT (PD1147), tonB (PD1319), potE (PD1257), PD1853, czcD (PD1811), sodM (PD1988), hxfA (PD2118), xanB (PD0212), and gumD (PD1394). X. fastidiosa WT, zur, and $c z c D$ strains were grown on PW agar plates supplemented with $25 \mu \mathrm{M} \mathrm{ZnSO}_{4}$ for 7 days. Three biological replicates were performed for each strain. For each replicate, cells were scraped from two plates and preserved in RNA Shield (Zymo Research, Austin, TX, U.S.A.) at $-80^{\circ} \mathrm{C}$. RNA was extracted using the Quick-RNA MiniPrep (Zymo Research) and concentrated with the RNA Clean \& Concentrator-5 (Zymo Research), including the in-column DNase I treatment, according to the manufacturer's instructions. RNA was quantified using a Qubit 2.0 Fluorometer with the Qubit RNA HS Assay Kit (Life Technologies, Grand Island, NY, U.S.A.). cDNA was synthesized with the qScript cDNA Synthesis Kit (Quanta Biosciences, Gaithersburg, MD, U.S.A.) from $50 \mathrm{ng}$ of RNA, according to the manufacturer's instructions. cDNA $(1 \mu \mathrm{l})$ was used for qPCR, with conditions as follows: reaction mixtures $(20 \mu \mathrm{l})$ contained 1× ABsolute Blue QPCR ROX mix (ABgeneThermo Fisher Scientific, Surrey, U.K.), 0.6 $\mu \mathrm{M}$ TaqMan probe (labeled with 5' 6-carboxyfluorescein and $3^{\prime}$ black hole quencher-1), and $1 \mu \mathrm{M}$ each primer. Samples were amplified using an ABI 7500 Real-Time PCR System (Applied Biosystems, Foster City, CA, U.S.A.) with the following cycling parameters: $95^{\circ} \mathrm{C}$ for $1 \mathrm{~min}$, followed by 40 cycles of $95^{\circ} \mathrm{C}$ for $15 \mathrm{~s}$ and $60^{\circ} \mathrm{C}$ for $1 \mathrm{~min}$. The fold change in gene expression was calculated by the threshold cycle $\left(2^{-\Delta \Lambda \mathrm{CT}}\right)$ method (Schmittgen and Livak 2008). Gene asnS was used as the endogenous control to normalize gene expression. Each qRT-PCR reaction was performed twice. Primers and probes used for gene expression analysis are listed in Supplementary Table S2. Two independent experiments were performed.

\section{Greenhouse virulence trials.}

N. tabacum 'Petite Havana SR1' (tobacco) seed (plant introduction number 552516) were obtained from the United States Department of Agriculture Germplasm Resources Information Network and germinated in Sunshine Mix number 8 (Sun Gro Horticulture Canada Ltd., Vancouver, Canada). Greenhouse temperature was maintained between 20 and $25^{\circ} \mathrm{C}$, with natural sunlight. After 1 month, 40 seedlings were transplanted into 4.5 -in. square pots. One week after transplanting, plants were fertilized with a slow-release fertilizer (Osmocote Outdoor \& Indoor Smart-Release Plant Food; The Scotts Company, Marysville, OH, U.S.A.).

At 3 weeks posttransplant, tobacco plants were prepared for inoculation as previously described (De La Fuente et al. 2013; Francis et al. 2008), by cutting the top of the stem so that only three healthy adult leaves in the lower portion of the plant remained. Bacterial inoculum was prepared from 7-day-old $X$. fastidiosa WT, zur, and $c z c D$ strains grown on PW or PW $+\mathrm{Km}$ solid media. Bacteria from two plates were scraped off and resuspended in succinate-citrate phosphate buffer (Minsavage et al. 1994) to a final $\mathrm{OD}_{600}$ of 0.25 . A 1 -ml tuberculin syringe with a 23 -gauge needle was used to inject the plants with $20 \mu \mathrm{l}$ of inoculum per each remaining petiole (three per plant), near the axils. Five plants were inoculated with each of the strains and five plants were injected with buffer only (control). After 1 week, the inoculation process was repeated for the same originally inoculated leaves.

Plants continued growing from the site where the stem was cut. At 60 to 80 days after the first inoculation, symptoms were rated and leaves were collected for further analysis. Bacterial populations in tobacco leaf petioles were quantified via qPCR, as described previously (De La Fuente et al. 2013). Briefly, a portion of the lower petiole (50 to $200 \mathrm{mg}$ ) of each leaf was excised and the weight of the tissue recorded. DNA from each tissue sample was extracted using the CTAB method described above. CFU values determined by qPCR were divided by the previously recorded weight of leaf tissue to determine $\mathrm{CFU} \mathrm{mg} \mathrm{m}^{-1}$ of leaf tissue. Two independent experiments were performed.

\section{Ionome characterization of inoculated plants.}

After excising the petioles, the leaves located four and seven internodes above the highest inoculated leaf were prepared for ionome analyses as described (De La Fuente et al. 2013), by drying at $65^{\circ} \mathrm{C}$ for $1 \mathrm{~h}$. The whole leaves were then crushed to a fine powder by a plastic mortar and pestle and sampled at 5 and $10 \mathrm{mg}$ of dry weight. Samples were digested for at $1 \mathrm{~h}$ at $100^{\circ} \mathrm{C}$ in $200 \mu \mathrm{l}$ of mineral-free concentrated nitric acid (OPTIMA, Fisher Scientific). After dilution with ultrapure, mineral-free water and centrifugation at $13,000 \times g$ to remove any remaining particulates, samples were analyzed by ICP-OES as previously described (Cobine et al. 2013), with simultaneous measurement of $\mathrm{B}, \mathrm{Ca}, \mathrm{Cd}, \mathrm{Co}, \mathrm{Cu}, \mathrm{Fe}, \mathrm{K}, \mathrm{Mg}, \mathrm{Mn}, \mathrm{Mo}, \mathrm{Na}, \mathrm{Ni}$, $\mathrm{P}, \mathrm{S}$, and $\mathrm{Zn}$. As controls, blanks of nitric acid were digested in parallel. Mineral concentrations were determined by comparing emission intensities to a standard curve created from certified mineral standards (SPEX CertiPrep). Repeated analysis of different amounts (5 and $10 \mathrm{mg}$ ) of individual samples showed less than $5 \%$ variation. For data analysis, the mineral concentrations determined for leaves located at four and seven internodes were summed as an indicator of the total mineral content of the plant. Two independent experiments were performed.

\section{Statistical analyses.}

Data from biofilm production, fringe width, and bacterial colonization of tobacco were analyzed by analysis of variance (ANOVA) (or Kruskal-Wallis for nonnormal data) and means compared by Fisher's least significance difference (LSD) test at the level of $P \leq 0.05$. The percentage of symptomatic leaves was subjected to the transformation arcsine [SQRT $(x)]$ and analyzed as described before. This transformation was done to satisfy ANOVA assumptions of normality and equal variance. The aforementioned analyses were conducted with SAS 9.2 (SAS Institute Inc., Cary, NC, U.S.A.). For the analysis of the ionome data, individual minerals were analyzed separately by one-way ANOVA and means compared by Tukey's highly significant difference test at the level of $P \leq 0.05$. For analysis of fold changes in gene expression, one-sample $t$ tests (fold change $\neq 1$, $P<0.05$ ) were calculated. The last two analyses were conducted using STATISTIX 8.0 software (Analytical Software, St. Paul, MN, U.S.A.).

\section{ACKNOWLEDGMENTS}

Funding for this research was provided by the National Science Foundation, Division of Mathematical Sciences (number 112-2343). Additional funding was obtained from the Department of Entomology and Plant Pathology, Auburn University and AAES-Hatch grant (number 0217494), and Agriculture and Food Research Initiative Competitive Grants Program grant number 2010-65108-20633 from the United States Department of Agriculture National Institute of Food and Agriculture. We thank S. Lindow (University of California, Berkeley) for providing a new stock of Temecula; P. Cobine (Auburn University) for access to and technical assistance with ICP-OES; personnel from Montaluce Winery (Dahlonega, GA, U.S.A.) for providing access to their vineyard; L. Cruz, J. Oliver, and S. Sefick for technical assistance and helpful discussions; and J. Parker for critical reading and editing of the manuscript. 


\section{LITERATURE CITED}

Andersen, P. C., Brodbeck, B. V., Oden, S., Shriner, A., and Leite, B. 2007. Influence of xylem fluid chemistry on planktonic growth, biofilm formation and aggregation of Xylella fastidiosa. FEMS (Fed. Eur. Microbiol. Soc.) Microbiol. Lett. 274:210-217.

Anton, A., Grosse, C., Reissmann, J., Pribyl, T., and Nies, D. H. 1999. CzcD is a heavy metal ion transporter involved in regulation of heavy metal resistance in Ralstonia sp. strain CH34. J. Bacteriol. 181:6876-6881.

Baxter, I. R., Vitek, O., Lahner, B., Muthukumar, B., Borghi, M., Morrissey, J., Guerinot, M. L., and Salt, D. E. 2008. The leaf ionome as a multivariable system to detect a plant's physiological status. Proc. Natl. Acad. Sci. U.S.A. 105:12081-12086.

Boyd, R. S. 2012. Plant defense using toxic inorganic ions: Conceptual models of the defensive enhancement and joint effects hypotheses. Plant Sci. 195:88-95.

Campoy, S., Jara, M., Busquets, N., Pérez De Rozas, A. M., Badiola, I., and Barbé, J. 2002. Role of the high-affinity zinc uptake znuABC system in Salmonella enterica serovar Typhimurium virulence. Infect. Immun. 70: 4721-4725.

Chatterjee, S., Almeida, R. P. P., and Lindow, S. 2008. Living in two worlds: The plant and insect lifestyles of Xylella fastidiosa. Annu. Rev. Phytopathol. 46:243-271.

Choi, H.-K., Iandolino, A., da Silva, F. G., and Cook, D. R. 2013. Water deficit modulates the response of Vitis vinifera to the Pierce's disease pathogen Xylella fastidiosa. Mol. Plant-Microbe Interact. 26:643-657.

Chvapil, M. 1973. New aspects in the biological role of zinc: A stabilizer of macromolecules and biological membranes. Life Sci. 13:1041-1049.

Ciavardelli, D., Ammendola, S., Ronci, M., Consalvo, A., Marzano, V., Lipoma, M., Sacchetta, P., Federici, G., Di Ilio, C., Battistoni, A., and Urbani, A. 2011. Phenotypic profile linked to inhibition of the major $\mathrm{Zn}$ influx system in Salmonella enterica: Proteomics and ionomics investigations. Mol. Biosyst. 7:608-619.

Cobine, P. A., Cruz, L. F., Navarrete, F., Duncan, D., Tygart, M., and De La Fuente, L. 2013. Xylella fastidiosa differentially accumulates mineral elements in biofilm and planktonic cells. PLoS One 8:e54936.

Cruz, L. F., Cobine, P. A., and De La Fuente, L. 2012. Calcium increases surface attachment, biofilm formation, and twitching motility in Xylella fastidiosa. Appl. Environ. Microbiol. 78:1321-1331.

Cruz, L. F., Parker, J. K., Cobine, P. A., and De La Fuente, L. 2014 Calcium-enhanced twitching motility in Xylella fastidiosa is linked to a single PilY1 homolog. Appl. Environ. Microbiol. 80:7176-7185.

Cursino, L., Li, Y., Zaini, P. A., De La Fuente, L., Hoch, H. C., and Burr, T. J. 2009. Twitching motility and biofilm formation are associated with tonB1 in Xylella fastidiosa. FEMS (Fed. Eur. Microbiol. Soc.) Microbiol. Lett. 299:193-199.

da Silva, F. R., Vettore, A. L., Kemper, E. L., Leite, A., and Arruda, P. 2001. Fastidian gum: The Xylella fastidiosa exopolysaccharide possibly involved in bacterial pathogenicity. FEMS (Fed. Eur. Microbiol. Soc.) Microbiol. Lett. 203:165-171.

Datnoff, L. E., Elmer, W. H., and Huber, D. M. 2007. Mineral Nutrition and Plant Disease. American Phytopathological Society, St. Paul, MN, U.S.A.

Davis, M. J., Purcell, A. H., and Thomson, S. V. 1980. Isolation media for the Pierce's disease bacterium. Phytopathology 70:425-429.

Davis, M. J., Whitcomb, R. F., and Gillaspie, A. G. J. 1981a. Fastidious bacteria of plant vascular tissue and invertebrates (including so called rickettsia-like bacteria). Pages 2172-2188 in: The Prokaryotes: A Handbook on Habitats, Isolation, and Identification of Bacteria. M. P. Starr, H. Stolp, H. G. Truper, A. Balows, and H. G. Schlegel, eds. Springer-Verlag, Berlin, New York.

Davis, M. J., French, W. J., and Schaad, N. W. 1981b. Axenic culture of the bacteria associated with phony disease of peach and plum leaf scald. Curr. Microbiol. 6:309-314.

De La Fuente, L., Parker, J. K., Oliver, J. E., Granger, S., Brannen, P. M., van Santen, E., and Cobine, P. A. 2013. The bacterial pathogen Xylella fastidiosa affects the leaf ionome of plant hosts during infection. PLoS One 8:e62945.

De La Fuente, L., Navarrete, F., Oliver, J. E., Cruz, L. F., and Cobine, P. A. 2014. The influence of metal elements on virulence in plant pathogenic bacteria. In: Virulence Mechanisms in Plant Pathogenic Bacteria. N. Wang, G. Sundin, L. De La Fuente, C. Roper, J. Ham, J. Jones, F. White, and S. Hogenhout, eds. American Phytopathological Society Press, St. Paul, MN, U.S.A

Doyle, J., and Doyle, J. L. 1987. Genomic plant DNA preparation from fresh tissue-CTAB method. Phytochem. Bull. 19:11-15.

Elsner, A., Kreikemeyer, B., Braun-Kiewnick, A., Spellerberg, B., Buttaro, B. A., and Podbielski, A. 2002. Involvement of Lsp, a member of the
LraI-lipoprotein family in Streptococcus pyogenes, in eukaryotic cell adhesion and internalization. Infect. Immun. 70:4859-4869.

Fones, H., and Preston, G. M. 2013. The impact of transition metals on bacterial plant disease. FEMS (Fed. Eur. Microbiol. Soc.) Microbiol. Rev. 37:495-519.

Fones, H., Davis, C. A. R., Rico, A., Fang, F., Smith, J. A. C., and Preston, G. M. 2010. Metal hyperaccumulation armors plants against disease. PLoS Pathog. 6:e1001093.

Francis, M., Civerolo, E. L., and Bruening, G. 2008. Improved bioassay of Xylella fastidiosa using Nicotiana tabacum cultivar SR1. Plant Dis. 92: $14-20$.

Gambetta, G. A., Fei, J., Rost, T. L., and Matthews, M. A. 2007. Leaf scorch symptoms are not correlated with bacterial populations during Pierce's disease. J. Exp. Bot. 58:4037-4046.

Ghaderian, Y. S. M., Lyon, A. J. E., and Baker, A. J. M. 2000. Seedling mortality of metal hyperaccumulator plants resulting from damping off by Pythium spp. New Phytol. 146:219-224.

He, Y. W., Ng, A. Y., Xu, M., Lin, K., Wang, L. H., Dong, Y. H., and Zhang, L. H. 2007. Xanthomonas campestris cell-cell communication involves a putative nucleotide receptor protein $\mathrm{Clp}$ and a hierarchical signalling network. Mol. Microbiol. 64:281-292.

Helman, J. D., Soonsanga, S., and Gabriel, S. 2007. Metalloregulators: Arbiters of metal sufficiency. Pages 37-66 in: Molecular Microbiology of Heavy Metals. D. H. Nies and S. Silver, eds. Springer-Verlag, Berlin.

Hobman, J. L., Yamamoto, K., and Oshima, T.2007. Transcriptomic responses of bacterial cells to sublethal metal ion stress. Pages 73-116 in: Molecular Microbiology of Heavy Metals. D. H. Nies and S. Silver, eds. Springer-Verlag, Berlin.

Hopkins, D. L., and Purcell, A. H. 2002. Xylella fastidiosa: Cause of Pierce's disease of grapevine and other emergent diseases. Plant Dis. 86 1056-1066.

Huang, D.-L., Tang, D. J., Liao, Q., Li, H.-C., Chen, Q., He, Y.-Q., Feng, J.-X., Jiang, B.-L., Lu, G.-T., Chen, B., and Tang, J.-L. 2008. The Zur of Xanthomonas campestris functions as a repressor and an activator of putative zinc homeostasis genes via recognizing two distinct sequences within its target promoters. Nucleic Acids Res. 36: 4295-4309.

Killiny, N., Martinez, R. H., Dumenyo, C. K., Cooksey, D. A., and Almeida, R. P. 2013. The exopolysaccharide of Xylella fastidiosa is essential for biofilm formation, plant virulence, and vector transmission. Mol. PlantMicrobe Interact. 26:1044-1053.

Lahner, B., Gong, J., Mahmoudian, M., Smith, E. L., Abid, K. B., Rogers, E. E., Guerinot, M. L., Harper, J. F., Ward, J. M., McIntyre, L., Schroeder, J. I., and Salt, D. E. 2003. Genomic scale profiling of nutrient and trace elements in Arabidopsis thaliana. Nat. Biotechnol. 21:1215-1221.

Lee, L. J., Barrett, J. A., and Poole, R. K. 2005. Genome-wide transcriptional response of chemostat-cultured Escherichia coli to zinc. J. Bacteriol. 187: 1124-1134.

Matsumoto, A., and Igo, M. M. 2010. Species-specific type II restrictionmodification system of Xylella fastidiosa temecula1. Appl. Environ. Microbiol. 76:4092-4095.

Matsumoto, A., Young, G. M., and Igo, M. M. 2009. Chromosome-based genetic complementation system for Xylella fastidiosa. Appl. Environ Microbiol. 75:1679-1687.

Mattick, J. S. 2002. Type IV pili and twitching motility. Annu. Rev. Microbiol. 56:289-314

Minsavage, G. V., Thompson, C. M., Hopkins, D. L., Leite, R., and Stall, R. E. 1994. Development of a polymerase chain-reaction protocol for detection of Xylella fastidiosa in plant tissue. Phytopathology 84:456-461.

Navarrete, F., and De La Fuente, L. 2014. Xylella fastidiosa response to zinc: Decreased culturability, increased exopolysaccharide production, and resilient biofilms under flow conditions. Appl. Environ. Microbiol 80:1097-1107.

Nies, D. H. 2003. Efflux-mediated heavy metal resistance in prokaryotes FEMS (Fed. Eur. Microbiol. Soc.) Microbiol. Rev. 27:313-339.

Ogasawara, H., Shinohara, S., Yamamoto, K., and Ishihama, A. 2012. Novel regulation targets of the metal-response BasS-BasR two-component system of Escherichia coli. Microbiology 158:1482-1492.

Oliver, J. E., Sefick, S. A., Parker, J. K., Arnold, T., Cobine, P. A., and De La Fuente, L. 2014. Ionome changes in Xylella fastidiosa-infected Nicotiana tabacum correlate with virulence and discriminate between subspecies of bacterial isolates. Mol. Plant-Microbe Interact. 27:1048-1058.

Panina, E. M., Mironov, A. A., and Gelfand, M. S. 2003. Comparative genomics of bacterial zinc regulons: Enhanced ion transport, pathogenesis, and rearrangement of ribosomal proteins. Proc. Natl. Acad. Sci. U.S.A. 100:9912-9917.

Park, S., and Ely, R. L. 2008. Genome-wide transcriptional responses of Nitrosomonas europaea to zinc. Arch. Microbiol. 189:541-548. 
Patzer, S. I., and Hantke, K. 1998. The ZnuABC high-affinity zinc uptake system and its regulator Zur in Escherichia coli. Mol. Microbiol. 28: 1199-1210.

Pedler, J. F., Webb, M. J., Buchhorn, S. C., and Graham, R. D. 1996. Manganese-oxidizing ability of isolates of the take-all fungus is correlated with virulence. Biol. Fertil. Soils 22:272-278.

Pompilio, A., Ciavardelli, D., Crocetta, V., Consalvo, A., Zappacosta, R., Di Ilio, C., and Di Bonaventura, G. 2014. Stenotrophomonas maltophilia virulence and specific variations in trace elements during acute lung infection: Implications in cystic fibrosis. PLoS One 9:e88769.

Rodrigues, C. M., Takita, M. A., Coletta-Filho, H. D., Olivato, J. C., Caserta, R., Machado, M. A., and de Souza, A. A. 2008. Copper resistance of biofilm cells of the plant pathogen Xylella fastidiosa. Appl. Microbiol. Biotechnol. 77:1145-1157.

Roper, M. C., Greve, L. C., Warren, J. G., Labavitch, J. M., and Kirkpatrick, B. C. 2007. Xylella fastidiosa requires polygalacturonase for colonization and pathogenicity in Vitis vinifera grapevines. Mol. Plant-Microbe Interact. 20:411-419.

Rossetti, C. A., Galindo, C. L., Garner, H. R., and Adams, L. G. 2011. Transcriptional profile of the intracellular pathogen Brucella melitensis following HeLa cells infection. Microb. Pathog. 51:338-344.

Salt, D. E., Baxter, I., and Lahner, B. 2008. Ionomics and the study of the plant ionome. Annu. Rev. Plant Biol. 59:709-733.

Schmittgen, T. D., and Livak, K. J. 2008. Analyzing real-time PCR data by the comparative C(T) method. Nat. Protoc. 3:1101-1108.

Shafeeq, S., Kloosterman, T. G., and Kuipers, O. P. 2011. Transcriptional response of Streptococcus pneumoniae to $\mathrm{Zn} 2+$ ) limitation and the repressor/activator function of AdcR. Metallomics 3:609-618.

Simpson, A. J. G., Reinach, F. C., Arruda, P., Abreu, F. A., Acencio, M., Alvarenga, R., Alves, L. M. C., Araya, J. E., Baia, G. S., Baptista, C. S., Barros, M. H., Bonaccorsi, E. D., Bordin, S., Bové, J. M., Briones, M. R. S., Bueno, M. R. P., Camargo, A. A., Camargo, L. E. A., Carraro, D. M., Carrer, H., Colauto, N. B., Colombo, C., Costa, F. F., Costa, M. C. R., Costa-Neto, C. M., Coutinho, L. L., Cristofani, M., Dias-Neto, E., Docena, C., El-Dorry, H., Facincani, A. P., Ferreira, A. J. S., Ferreira, V. C. A., Ferro, J. A., Fraga, J. S., França, S. C., Franco, M. C., Frohme, M., Furlan, L. R., Garnier, M., Goldman, G. H., Goldman, M. H. S., Gomes, S. L., Gruber, A., Ho, P. L., Hoheisel, J. D., Junqueira, M. L., Kemper, E. L., Kitajima, J. P., Krieger, J. E., Kuramae, E. E., Laigret, F., Lambais, M. R., Leite, L. C. C., Lemos, E. G. M., Lemos, M. V. F., Lopes, S. A., Lopes, C. R., Machado, J. A., Machado, M. A., Madeira, A. M., Madeira, H. M. F., Marino, C. L., Marques, M. V., Martins, E. A. L., Martins, E. M. F., Matsukuma, A. Y., Menck, C. F. M., Miracca, E. C., Miyaki, C. Y., Monteriro-Vitorello, C. B., Moon, D. H., Nagai, M. A., Nascimento, A. L., Netto, L. E. S., Nhani, A., Jr., Nobrega, F. G., Nunes, L. R., Oliveira, M. A., de Oliveira, M. C., de Oliveira, R. C., Palmieri,
D. A., Paris, A., Peixoto, B. R., Pereira, G. A. G., Pereira, H. A., Jr., Pesquero, J. B., Quaggio, R. B., Roberto, P. G., Rodrigues, V., de M Rosa, A. J., de Rosa, V. E., Jr., de Sá, R. G., Santelli, R. V., Sawasaki, H. E., da Silva, A. C. R., da Silva, A. M., da Silva, F. R., da Silva, W. A., Jr., da Silveira, J. F., Silvestri, M. L. Z., Siqueira, W. J., de Souza, A. A., de Souza, A. P., Terenzi, M. F., Truffi, D., Tsai, S. M., Tsuhako, M. H., Vallada, H., Van Sluys, M. A., Verjovski-Almeida, S., Vettore, A. L., Zago, M. A., Zatz, M., Meidanis, J., and Setubal, J. C. 2000. The genome sequence of the plant pathogen Xylella fastidiosa. The Xylella fastidiosa Consortium of the Organization for Nucleotide Sequencing and Analysis. Nature 406:151-159.

Sun, Q., Sun, Y., Walker, M. A., and Labavitch, J. M. 2013. Vascular occlusions in grapevines with Pierce's disease make disease symptom development worse. Plant Physiol. 161:1529-1541.

Tang, D. J., Li, X. J., He, Y. Q., Feng, J. X., Chen, B., and Tang, J. L. 2005. The zinc uptake regulator Zur is essential for the full virulence of Xanthomonas campestris pv. campestris. Mol. Plant-Microbe Interact. 18:652-658.

Untergrasser, A., Cutcutache, I., Koressaar, T., Ye, J., Faircloth, B. C., Remm, M., and Rozen, S. G. 2012. Primer3 - new capabilities and interfaces. Nucleic Acids Research 40:e115.

Waldron, K. J., Rutherford, J. C., Ford, D., and Robinson, N. J. 2009. Metalloproteins and metal sensing. Nature 460:823-830.

Wang, J., Mushegian, A., Lory, S., and Jin, S. 1996. Large-scale isolation of candidate virulence genes of Pseudomonas aeruginosa by in vivo selection. Proc. Natl. Acad. Sci. U.S.A. 93:10434-10439.

Yang, W., Liu, Y., Chen, L., Gao, T., Hu, B., Zhang, D., and Liu, F. 2007. Zinc uptake regulator (zur) gene involved in zinc homeostasis and virulence of Xanthomonas oryzae pv. oryzae in rice. Curr. Microbiol. 54: 307-314.

Yuan, M., Chu, Z., Li, X., Xu, C., and Wang, S. 2010. The bacterial pathogen Xanthomonas oryzae overcomes rice defenses by regulating host copper redistribution. Plant Cell 22:3164-3176.

Zaini, P. A., Fogaça, A. C., Lupo, F. G. N., Nakaya, H. I., Vêncio, R. Z. N., and da Silva, A. M. 2008. The iron stimulon of Xylella fastidiosa includes genes for type IV pilus and colicin V-like bacteriocins. J. Bacteriol. 190:2368-2378.

Zaini, P. A., De La Fuente, L., Hoch, H. C., and Burr, T. J. 2009. Grapevine xylem sap enhances biofilm development by Xylella fastidiosa. FEMS (Fed. Eur. Microbiol. Soc.) Microbiol. Lett. 295:129-134.

Zhang, X. X., and Rainey, P. B. 2007. Genetic analysis of the histidine utilization (hut) genes in Pseudomonas fluorescens SBW25. Genetics $176: 2165-2176$

Zhang, X. X., and Rainey, P. B. 2008. Regulation of copper homeostasis in Pseudomonas fluorescens SBW25. Environ. Microbiol. 10:32843294 